\title{
Expansionary Japanese budget provides little extra for science
}

\section{Tokyo}

THE Japanese cabinet has approved its first expansionary budget in six years. But two of the leading science-related ministries, the Ministry of International Trade and Industry (MITI) and the Science and Technology Agency, have gained little in the way of extra funds for research. Nevertheless, some new projects will be launched by diverting funds from other programmes.

The general account budget for fiscal year 1988, which, subject to Diet approval, comes into effect in April, stands at $¥ 56.7$ million million $(\$ 436,000$ million), nearly 5 per cent up on last year. Despite a rigid policy aimed at eliminating the issuing of deficit-financing bonds by 1990 , the budget has been boosted by the sale of shares of Nippon Telegraph and Telephone - when the first shares were released on the stock market last year, they shot up in price from $¥ 1.2$ million to more than $¥ 3$ million each and the government was able to sell the second batch at more than twice the original price. Further sales are planned this year and, provided the market can absorb them, the government stands to make millions of millions of yen. But most of the extra funds are being funnelled into public works, defence and overseas development; the increases for science and technology are miserly.

Despite their tight budgets, MITI and the agency have managed to pump sub-

\section{Japanese science budget}

\begin{tabular}{|c|c|c|c|c|}
\hline Science and Technology Agency & \multicolumn{3}{|c|}{ (thousand million yen) } & $\begin{array}{l}\text { (\% chang } \\
\text { from } 1987\end{array}$ \\
\hline $\begin{array}{l}\text { Total research and } \\
\text { development budget }\end{array}$ & 427.8 & 432.5 & 440.2 & $(+1.8)$ \\
\hline Special promotion funds & 7.9 & 8.4 & 9.2 & $(+9.5)$ \\
\hline Space & 92.6 & 94.6 & 98.5 & $(+4.1)$ \\
\hline Nuclear energy & 275.2 & 273.4 & 271.5 & $(-0.7)$ \\
\hline Ocean research & 6.6 & 7.7 & 9.3 & $(+23.4)$ \\
\hline ERATO & 2.7 & 3.2 & 3.8 & $(+20.8)$ \\
\hline $\begin{array}{l}\text { International frontier } \\
\text { research system }\end{array}$ & 1.1 & 1.5 & 1.5 & $(-1.3)$ \\
\hline \multicolumn{5}{|c|}{ Ministry of International Trade and Industry } \\
\hline $\begin{array}{l}\text { Total technology development } \\
\text { budget }\end{array}$ & 217.6 & 221.4 & 221.2 & $(-0.1)$ \\
\hline Japan key technology centre & 20.5 & 25.0 & 26.0 & $(+4.0)$ \\
\hline $\begin{array}{l}\text { Basic technology for future } \\
\text { industries }\end{array}$ & 6.5 & 6.0 & 6.4 & $(+6.6)$ \\
\hline Large-scale industrial projects & 15.2 & 15.1 & 13.6 & $(-10.0)$ \\
\hline Sunshine project & 43.0 & 44.1 & 37.8 & $(-14.3)$ \\
\hline Moonlight project & 12.3 & 11.4 & 9.7 & $(-14.9)$ \\
\hline $\begin{array}{l}\text { Fifth-generation computer } \\
\text { project }\end{array}$ & 5.5 & 5.6 & 5.7 & $(+1.8)$ \\
\hline Unmanned space platform & 0.2 & 0.4 & 0.5 & $(+16.3)$ \\
\hline $\begin{array}{l}\text { Medical technology } \\
\text { development }\end{array}$ & 0.7 & 0.7 & 0.7 & $(0.0)$ \\
\hline $\begin{array}{l}\text { Promotion of research } \\
\text { cooperation with developing } \\
\text { countries }\end{array}$ & 0.8 & 1.0 & 1.2 & $(+20.0)$ \\
\hline $\begin{array}{l}\text { Human frontiers science } \\
\text { program }\end{array}$ & 0.02 & 0.2 & $0.5^{*}$ & $(+135.0)$ \\
\hline
\end{tabular}

stantial funds into superconductor research. The agency will get $¥ 3,192$ million ( $\$ 25$ million), including $¥ 2,044$ million for research on the new high-temperature superconductors. The outlays include $¥ 895$ million for a 40-tesla superconducting magnet at the National Research Institute of Metals and $¥ 270$ million for a super high-powered electron microscope at the National Research Institute for Inorganic Materials.

MITI will get $¥ 3,370$ million for superconductors: $¥ 1,060$ million as 'basic technology for future industries’; $¥ 1,650 \mathrm{mil}$ lion to build a $70,000-\mathrm{kW}$ superconducting generator from conventional superconductors under MITI's energy-saving 'Moonlight' project’; and $¥ 140$ million to assess world supplies of the rare-Earth elements needed to make the ceramics.

The Science and Technology Agency's space programme gets a substantial boost, but nearly all the extra funds go to continuing development of the $\mathrm{H}-2$ rocket scheduled for launch in 1992. And the increased outlay for ocean research is almost entirely for the deep-sea submersible Shinkai 6500 which is scheduled for completion in fiscal year 1989.

All these gains have been made at the expense of energy-related research. The agency's budget for nuclear energy has shown a steady decline over the past three years. Nevertheless $¥ 950$ million ( $\$ 7$ million) has been allocated for the a new experimental high-temperature gascooled reactor at the Japan Atomic Energy Research Institute. MITI's outlays for alternative energy sources under the 'Sunshine' project have also been severely cut back. But Japan still maintains substantial alternative energy and nuclear energy research programmes.

Basic science has suddenly become a hot issue in Japan (see Nature 331, 6; 1988), and both MITI and the Science and Technology Agency have won substantial increases for their small basic research programmes. The agency's ERATO programme, which supports novel, sometimes eccentric, basic research will get three new projects this year on 'pico-second chemistry', 'quantum function structure' and 'information materials in plants'. The International Frontier $\mathrm{Re}$ -

\section{Microchip makers gather in Texas \\ Washington}

THE US semiconductor industry's plans to regain ground lost to its Japanese competitors took a step forward last week with the choice of Austin, Texas, as the site for a new cooperative research facility. Sematech, a consortium formed by the nation's 14 largest computer-chip manufacturers, will begin setting up soon and aims to have experimental microchip manufacturing lines running this year.

The announcement follows a congressional decision to provide Sematech with $\$ 100$ million a year for the next five years. The remainder of the consortium's \$250-million-a-year budget will come from member companies and state governments. Choice of the site was not easy: 34 states offered 135 locations. Austin came out on top because it had an excellent building, an old Data General Corporation plant, all ready to use, and could offer a close relationship with the University of Texas. The presence of the Microelectronics and Computer Technology Corporation, a similar consortium was also in Austin's favour. Around 800 people will be employed at Sematech.

Exactly what Sematech will do still remains undecided, despite a year of debate. Its emphasis is likely to be on developing production equipment that can beat the standards set by Japanese manufacturers in efficiently mass-producing sub-micron memory chips. But Japanese manufacturers appear to be so far ahead of their US competitors that some of the consortium members feel that it should concentrate on what the US already does well - designing and manufacturing custommade chips for special purposes - rather than trying to rival Japan's skills in mass production. Others contend that individual US companies are strong enough to hold on to the lead in custom-chip design and that the industry needs to act together only in areas where Japan is supreme. A clearer focus is likely to emerge soon after a chief executive is chosen this month.

Alun Anderson

search System gets a new project to study the function of the brain.

Funds for the much-discussed Human Frontier Science Program are more than doubled. But most of the money ( $¥ 300$ million from the agency's 'Special Promotion Funds') will go to "more detailed studies, international meetings, and to confirm the feasibility of expected Frontiers activities". MITI officials deny that this is a continuation of the feasibility study that has been dragging on for over a year. But only $¥ 170$ million (just over \$1 million) is assigned to actual research on biological functions. David Swinbanks 